\title{
Consecutive earthquakes temporarily restructured the zooplankton community in an Alpine Lake
}

\author{
Anton Brancelj ${ }^{1,2}$, Uroš Žibrat ${ }^{1}$, Tadej Mezek ${ }^{1}$, Irena Rejec Brancelj ${ }^{3}$ and Henri J. Dumont ${ }^{4 *}$ \\ 1 National Institute of Biology, Večna pot 111, 1000 Ljubljana, Slovenia \\ 2 Faculty of Environmental Sciences, University of Nova Gorica, Vipavska 13, 5000 Nova Gorica, Slovenia \\ 3 Anton Melik Geographical Institute, ZRC SAZU, Gosposka ulica 13, 1000 Ljubljana, Slovenia \\ ${ }^{4}$ Department of Biology, State University of Ghent, K.L. Ledeganckstraat 35, 9000 Ghent, Belgium
}

Received 10 May 2011; Accepted 18 October 2011

\begin{abstract}
Two consecutive earthquakes temporary changed a zooplankton community in a high-mountain Lake Krn (altitude $1383 \mathrm{~m}$ a.s.l.). It was dominated by the eurytherm copepod, Cyclops vicinus, until 1998, when the first earthquake hit the lake (EMS =5.6). After the earthquake, the population of $C$. vicinus collapsed and the thermophilic cladoceran, Ceriodaphnia quadrangula, took over. After the second earthquake in 2004 (EMS = 4.0), C. vicinus became untraceable. In 2008, few copepods reappeared and by 2010 they became the sole dominant again. Only Secchi-disc depth showed a statistically significant increase over time, while $N_{\text {tot }}, P_{\text {tot }}$ and temperature showed an increasing trend, yet the relationship was insignificant. To compare multi-parameter properties of the water column, the studied period was divided into Period 1 (before the first earthquake), Period 2 (between earthquakes) and Period 3 (after the second earthquake). A Hotteling $T^{2}$ test confirmed a statistically significant difference between Periods 1 and $2 \& 3(P<0.01)$, but not between Periods 2 and $3(P>0.1)$. During simple laboratory experiment, specimens of $C$. vicinus were covered with a thin layer of sediment, to mimic the earthquake's effect on their survival. A hypothesis was that the timing of both earthquakes had been crucial for decimation of $C$. vicinus population as they re-suspended sediment with hibernating copepodites. As these became subsequently buried they were deprived of a re-activation signal and exposed prolonged anoxic conditions there. C. quadrangula temporary filled the void left by the copepod, which needed 6 years to regain its dominance.
\end{abstract}

Key words: Competition / earthquake / high-mountain lake / invasion / zooplankton community

\section{Introduction}

High-altitude lakes in Europe and North America arose at the end of the last ice-age, approximately 15000 10000 years ago. Such alpine lakes are mostly small and sensitive to external or internal disturbance as their biological processes are slowed by low temperatures and/ or short ice-free periods (Battarbee et al., 2002; Catalan et al., 2002, 2009). Their zooplankton communities are simple, and usually consist of one or two taxa of Calanoida, one Cyclopoida, one or two Cladocera, and some Rotifera (Luger et al., 2000; Cavalli et al., 2001; Jersabek et al., 2001; Brancelj, 2002; Schabetsberger et al., 2006, 2009). Analyses of sediment cores have revealed some changes in the species composition of their zooplankton and benthos, but most of these were caused by

\footnotetext{
*Corresponding author: Henri .Dumont@UGent . be
}

fish introduction, pollution, or climate change that rapidly altered the structure of these communities (for relevant references, see below).

Originally, high-mountain lakes were fishless. However, since the 15th century, most lakes in the Alps and elsewhere in Europe, and later also in North America, have been stocked with fish, predominantly with Arctic char and brown trout (Schabetsberger et al., 2009). This induced incisive changes in zooplankton, reflected in novel species compositions and/or shifts in size classes (Goyke and Hershey, 1992; Johnson et al., 1996; Schabetsberger et al., 2006). Ultimately fish can even eliminate all crustaceans while rotifers proliferate, and shift the lake ecosystem towards eutrophication (Brancelj, 1999; Brancelj et al., 2000a; Brancelj, personal observation).

After 1850, atmospheric pollution caused a $\mathrm{pH}$ decrease in lakes with low alkalinity (Wograth and Psenner, 1995; Šporka et al., 2002). Many pH-sensitive 
species (plants as well as animals) declined or disappeared (Fott et al., 1994; Cammarano and Manca, 1997; Gulizzoni et al., 2006; Hořická et al., 2006; Sacherová et al., 2006).

Evidence that naturally occurring physical disturbances can have similar effects on zooplankton are rare, except for climate change. In the last two decades, many papers have dealt with the effects of recent (i.e., within last two centuries) climate change on water chemistry and biota in high-mountain lakes. Among the first studies on the effects of climate change on water chemistry (and consequently on biota) in an acidified mountain lake was that on the shallow lake, Hazenbach (Austria), where pH values increased during dry summer periods (Theis, 1994). Experiments indicated that fluctuations of allochthonous dissolved organic matter, as a result of droughts and longterm climatic change, can affect littoral food webs (Vinebrooke and Leavitt, 1998). Complex studies on the effects of increased air and water temperature on biological processes in mountain lakes were performed in the 1990s (the MOLAR project: http://emergent.mountainlakes.org/molar/; Koinig et al., 2002; Catalan et al., 2002; Heiri and Lotter, 2003). Most of these studies, however, focused on diatoms and chironomids.

Among the indirect physical effects of climate change on lake biota are increased amounts of turbid glacial meltwater, which affect the vertical distribution of phyto- and zooplankton through attenuation of photosynthetically active radiation and ultraviolet radiation (Sommaruga, 2001; Samuel et al., 2011). A similar effect in shallow lakes is wind-induced sediment re-suspension, which affects many physical and biological processes, including food gathering by zooplankton. In lakes with prolonged or frequent sediment re-suspension, the zooplankton community can be altered (Levine et al., 2005).

Physical disturbances that last for short periods (seconds/minutes/hours) and are not climate-dependent, but can have long-lasting effects on land and aquatic ecosystems are earthquakes. They trigger landslides and erosion, temporarily increasing water turbidity (Korup et al., 2004). On land, they can locally result in tilted and damaged trees (Carrara and O'Neill, 2003), while in lakes they can induce mud flows of considerable thickness (Nomade et al., 2005).

Earthquake effects on aquatic animals are little known, although effects can be expected, especially when mud flows are extensive. The affected groups are predominantly benthic. Among the rare, recorded effects of seismic activities on aquatic animals is a report from Lake Baikal, where an earthquake on August 1912 released a large amount of methane into the water column, causing a mass-kill of Baikal oil fish (Comephorus baikalensis (Pallas, 1776) and C. dybowskii Korotneff, 1905) (Radziminovich et al., 2010). A few days before the strong earthquake (European Magnitude Scale/EMS/ $=6.3$ ) that hit L'Aquila (Italy) on April 6, 2009 common toads (Bufo bufo Linneaus, 1758) disappeared from their breeding site and did not return until after the aftershock series declined (Grant et al., 2011). The authors presumed

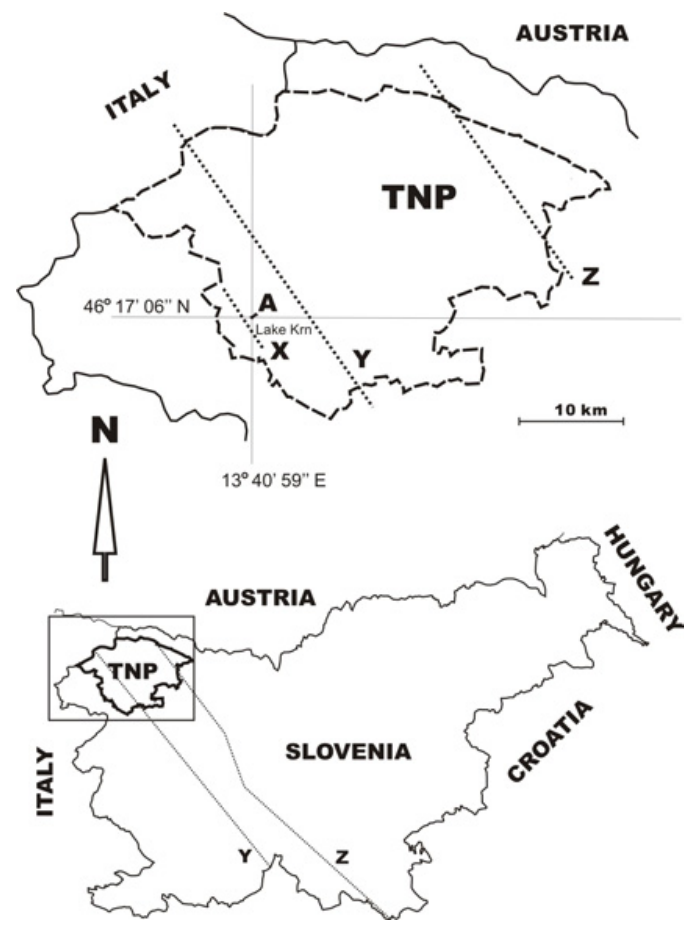

Fig. 1. TNP (Slovenia) with the studied lake (A: Lake Krn). Two main faults (Y: Idrija; Z: Želimlje) and a local one (X), where the main effects occurred are indicated (after Vidrih, 2008).

that changes in ground water chemistry, as a result of production of hydrogen peroxide prior to seismic events, were the reason for this behaviour.

To date, no data pertaining to the effects of earthquakes on zooplankton are known. Theoretically, it can be affected if land- or in-lake sediment slides enrich the water column with nutrients released from re-suspended sediment and, thereby, increase primary production. Over the last 700 years, 17 earthquakes sufficiently strong to trigger landslides have occurred in the south-eastern part of the Alps (Vidrih, 2008). Seven of them occurred after 1900. Two very strong earthquakes hit the area on April 12, 1998 $($ EMS = 5.6; earthquake I) and June 12, 2004 (EMS = 4.0; earthquake II), with an epicentre adjacent to Lake Krn in NW part of Slovenia (Fig. 1, line X). Both triggered landslides on the surrounding slopes but none entered the lake. Albeit soon after both earthquakes, a change in the zooplankton community composition occurred.

Here, we describe the changes that took place over a period of 17 years, and test our insights into the mechanism leading from an earthquake to a faunal change and return by setting up some simple laboratory experiments.

\section{Methods}

\section{Site description}

The lake, situated at $1383 \mathrm{~m}$ a.s.1. within the Triglav National Park (TNP) (Fig. 1) in the south-eastern part of 
the Alps, a tectonically active area, has a surface area of 4.5 ha and a maximum depth of $17 \mathrm{~m}$. In the radius of $c .20$ km 12 more high-mountain lakes are present, situated between 1430 and $2150 \mathrm{~m}$ a.s.l., all smaller and shallower than Lake Krn. Ice cover on Lake Krns lasts between midNovember and March/April and thermal stratification between July and mid-September. It is dimictic and holomictic, with a temporary inflow as a torrent and outflow through a sinkhole on the shoreline. It is oligomesotrophic, with average Secchi-disc depth of between 5 and $7 \mathrm{~m}$ and with a trend of increased transparency in the last decade. In total, 53 taxa of algae occur in open water, with Chlorophyceae (16 taxa) and Conjugatae (12 taxa) the most abundant (Šiško and Kosi, 2002). Short-term hypoxia/anoxia occurs regularly in the $5 \mathrm{~m}$ of water just above the bottom in late winter/early spring and at the end of summer (Dobravec and Siško, 2002). Fish (Arctic char - Salvelinus alpinus (Linnaeus, 1758) and minnow - Phoxinus phoxinus (Linnaeus, 1758)) were introduced only once, in 1927.

\section{Sampling}

Zooplankton and limnological features (temperature of the water column, conductivity, major ions, Secchi-disc depth and chlorophyll $=\mathrm{Chl}-a$ ) have been monitored between 1994 and 2010 above the deepest sector of the lake. Monitoring was conducted within the first two weeks of September, when the thermal stratification and plankton community were well developed. In the second half of September, rain normally starts in the area and stratification collapses, followed by a correlative decrease in zooplankton. Physical and chemical variables were measured at $2.5 \mathrm{~m}$ intervals from surface to bottom. Additional samples for studying the population dynamics of Cyclops vicinus (Uljanin, 1875), were taken as part of EU projects MOLAR and EMERGE on limnology and paleolimnology of high-mountain lakes between May 1996 and August 2000 (Catalan et al., 2009). During both projects, zooplankton samples were collected 4-5 times during ice-free period and once during ice-cover or just after ice-melt each year. Within the MOLAR project, sediment samples were collected with a Kajak's gravity corer (three sediment cores, length: 50-70 cm; diameter: $5 \mathrm{~cm}$ ) in order to analyse sub-fossils, particularly of Cladocera. Zooplankton (for monitoring and additional samples) was sampled with standard plankton nets (length: $1.5 \mathrm{~m}$; mesh size: $100 \mu \mathrm{m}$; diameter: $20 \mathrm{~cm}$ ) over the entire water column. On each sampling date, a set of three hauls (i.e., replicates) for qualitative analyses and a set of three hauls for quantitative analyses were collected. For each set of analyses, 1600 litres of the water column was filtered $(20 \mathrm{~cm}$ of net diameter $\times 17 \mathrm{~m}$ depth $\times 3$ replicates). Each set of hauls was amalgamated in plastic bottles and stored in formaldehyde (1994-2005) or in 70\% alcohol (onwards from 2006). An identical autumn monitoring program was performed also on other 12 lakes within TNP.
Long-term epilimnion temperatures (October 2000 to September 2010) were obtained using an 8-bit Minilog-TX sensor (Vemco Ltd, Canada, resolution $0.1{ }^{\circ} \mathrm{C}, 6 \mathrm{~h}$ sampling interval), which was placed $0.5 \mathrm{~m}$ below the surface above the deepest point of the lake. For statistical analyses, we included only temperatures $\geq 4{ }^{\circ} \mathrm{C}$ and measured daily at $18.00 \mathrm{~h}$. Average epilimnion temperatures were calculated as mean values of epilimnion during the first two weeks of September.

In September 2007, a census of fish population in the lake was performed. Overnight, $150 \mathrm{~m}$ of multi-mesh gill nets were stretched across the lake, from the surface to the depth of $5 \mathrm{~m}$. Next morning, fish were removed from the nets, identified and counted. Samples for stomach analyses were stored in $60 \%$ alcohol.

\section{Laboratory analyses}

Zooplankton biomass was calculated after samples were dried at $60{ }^{\circ} \mathrm{C}$ for $24 \mathrm{~h}$ and weighed to the nearest $0.1 \mathrm{mg}$. Zooplankton samples were sub-sampled and species relative abundance determined (as \%).

For the analysis of the population dynamics of C. vicinus, the animals were divided into four groups (males, females with and without egg sacs, copepodites) and their absolute and relative abundance determined.

Stomach content of fish was emptied on a mesh screen (mesh size $100 \mu \mathrm{m}$ ), washed to remove fine particles and then transferred to a Petri dish. Qualitative determination of stomach content was done at $\times 40$ magnification to the lowest possible taxonomic level.

Total phosphorus $\left(P_{\text {tot }}\right.$, in $\mu$ g P.L $\left.{ }^{-1}\right)$, total nitrogen $\left(N_{\text {tot }}\right.$, in $\mathrm{mg} \mathrm{N} . \mathrm{L}^{-1}$ ), and alkalinity (in $\mu$ eqv. $\mathrm{L}^{-1}$ ) were measured from 1994 onwards. Samples for chlorophyll $a$ analysis were treated according to Clesceri et al. (1998) and measured with a UV-Vis spectrophotometer at 664 , 647 and $630 \mathrm{~nm}$. Concentrations were calculated after Jeffrey and Humprey (1975).

\section{Statistical analyses}

Data on lake chemistry and biology were separated into three periods: before the first earthquake (September 1994-April $1998=$ Period 1), between the first and second earthquake (April 1998-June 2004=Period 2) and after the second earthquake (June 2004-September $2010=$ Period 3). Univariate differences among these three groups were tested using Tukey's HSD ANOVA test. The validity of these clusters for biological data was evaluated with a stratigraphically constrained cluster analysis (Grimm, 1987). To minimize the effect of each environmental variable's distribution down the water column, the data for each year were normalized by calculating the Student's $t$-statistic.

Multiple regression was used for estimating the effects of individual environmental variables on $C$. vicinus and Ceriodaphnia quadrangula (O.F. Müller, 1785) dynamics. 
Table 1. Tukey's HSD ANOVA test on environmental parameters in Lake Krn (Slovenia) (only comparisons with significant differences are shown; P1 = period 1 (1994-1998); P2 = period 2 (1999-2003), P3 = period 3 (2004-2010)).

\begin{tabular}{llccr}
\hline Comparison & & Difference of means & $q$ & \multicolumn{1}{c}{} \\
\hline Secchi-disc depth & P1:P3 & 2.68 & 4.58 & $<.11$ \\
& P2:P3 & 2.85 & 3.73 & $<0.01$ \\
Temperature & P2:P3 & 0.505 & 3.47 & $<0.05$ \\
Alkalinity & P1:P2 & 0.59 & 3.54 & $<0.05$ \\
Conductivity & P1:P2 & 0.49 & 3.44 & $<0.01$ \\
& P2:P3 & 0.39 & 0.05 \\
\hline
\end{tabular}

Environmental variables were chosen with a backward selection procedure. In addition, differences between individual environmental variables, separated into the three periods, were assessed using a $t$ test. Differences in multivariate space among the three periods were then assessed with a Hotelling $T^{2}$ test.

In order to check for any gradients present in the data, we also performed a constrained ordination analysis (canonical correspondence analysis - CCA). Species present in less than three samples were not included in the analysis. The environmental data included Secchi-disc depth, average epilimnion temperature, alkalinity, $P_{\text {tot }}, N_{\text {tot }}$, Chl- $a$, total zooplankton biomass and conductivity. The statistical analyses were carried out in Past (Hammer et al., 2001), KyPlot v. 2.0 beta 13 and Canoco 4.5 (ter Braak and Smilauer, 2002).

\section{Laboratory experiment with $C$. vicinus copepodites}

To test the hypothesis that hibernating $C$. vicinus copepodites can be eliminated by burial in sediment resuspended by an earthquake at low oxygen concentrations, a laboratory experiment was performed. Pelagic stages of $C$. vicinus, collected at the end of July, were used in the experiment. Two sets of six transparent plastic tubes (diameter: $6 \mathrm{~cm}$; length: $90 \mathrm{~cm}$ ), filled with $15 \mathrm{~cm}$ of lake sediment, and were topped with c. $20 \mathrm{~cm}$ of water. First, 50 C. vicinus copepodites (stages CIV and CV, i.e., adults) were narcotised with $\mathrm{CO}_{2}$ and transferred to tubes with oxygenated lake water. Two tubes served as controls; four were put in a laboratory shaker (IKA 501 digital) for $12-15 \mathrm{~s}$ at $5 \mathrm{~Hz}$ to mimic an earthquake. Tubes were kept in vertical position, stored in dark at $8{ }^{\circ} \mathrm{C}$ and checked after $24 \mathrm{~h}$ for recovery of test animals. In the second part, all procedures remained unchanged except that oxygen concentration was reduced to $c$. $10 \%$ by adding $\mathrm{CO}_{2}$ from a siphon bottle before transferring the animals to the tubes. Again, two tubes were left intact and four were stirred on the laboratory shaker. After $24 \mathrm{~h}$ tubes were aerated to $100 \%$ of saturation and after additional $24 \mathrm{~h}$ checked for recovery of the animals. Animals were narcotised with $\mathrm{CO}_{2}$ to keep them immobile during the very first period of experiment - i.e., re-suspension of sediment and settling down to the bottom, where they were partly or completely covered by sediment.

\section{Results}

\section{Environmental conditions}

Only Secchi-disc depth showed a statistically significant correlation with time (Pearson, $r=0.692, P<0.01$ ). $N_{\text {tot }}$, $P_{\text {tot }}$ and temperature also show an increasing trend, yet the relation is insignificant. On the other hand, $\mathrm{PO}_{4}^{3+}$ shows a decreasing, marginally significant trend. Results were confirmed with a Tukey's HSD ANOVA test, comparing the three time periods. Secchi-disc depth $(P<0.01)$, temperature $(P<0.05)$, alkalinity $(P<0.05)$ and conductivity (Period 1:Period $2 P<0.01$, Period 2:Period 3 $P<0.05)$ exhibited the greatest differences among the three periods (Tab. 1).

In multivariate space, the pattern is somewhat different Period 1 (prior to the first earthquake) forms a distinct cluster, representing samples with smaller Secchi-disc depth and lower average epilimnion temperatures, conductivity, alkalinity and $\mathrm{SO}_{4}^{2+}$ concentrations (principal component analysis; results not shown). A Hotteling $T^{2}$ test confirmed a statistically significant difference between Periods 1 and 2 and $3(P<0.01)$, while between Periods 2 and 3 the difference was insignificant $(P>0.1)$.

Instrumental records alone show that during an ice-free period (i.e., water temperature $\geq 4{ }^{\circ} \mathrm{C}$ ), between 2000 and 2010, a slight trend of increase in surface water temperature $\left(y=0.003 x+11.906 ; R^{2}=0.0045\right)$ occurred. Maximum surface temperatures were between $19^{\circ} \mathrm{C}$ (in 2004) and $23{ }^{\circ} \mathrm{C}$ (in 2010).

\section{Fish census and stomach content}

In $12 \mathrm{~h}$, four specimens of Arctic char were caught (10, 11,14 and $18 \mathrm{~cm}$ in length) and 75 minnows. All the minnows and small Arctic chars were collected less than $5 \mathrm{~m}$ from the shore, while the big arctic char was caught about $15 \mathrm{~m}$ from the shore. A survey in September 2007 revealed that: (a) the population of Arctic char is rather low and (b) minnows do not enter the pelagic zone.

Analyses of stomach content of fish revealed that one specimen of Arctic char had a small minnow in its stomach. In other two specimens, diet consisted of larvae and adult insects (Trichoptera, Ephemeroptera, Diptera: Chironomidae). Only the smallest specimens $(10 \mathrm{~cm}$ in length) also fed on littoral Cladocera and Copepoda (Chydorus sphaericus (O.F. Müller, 1785), Eucyclops 


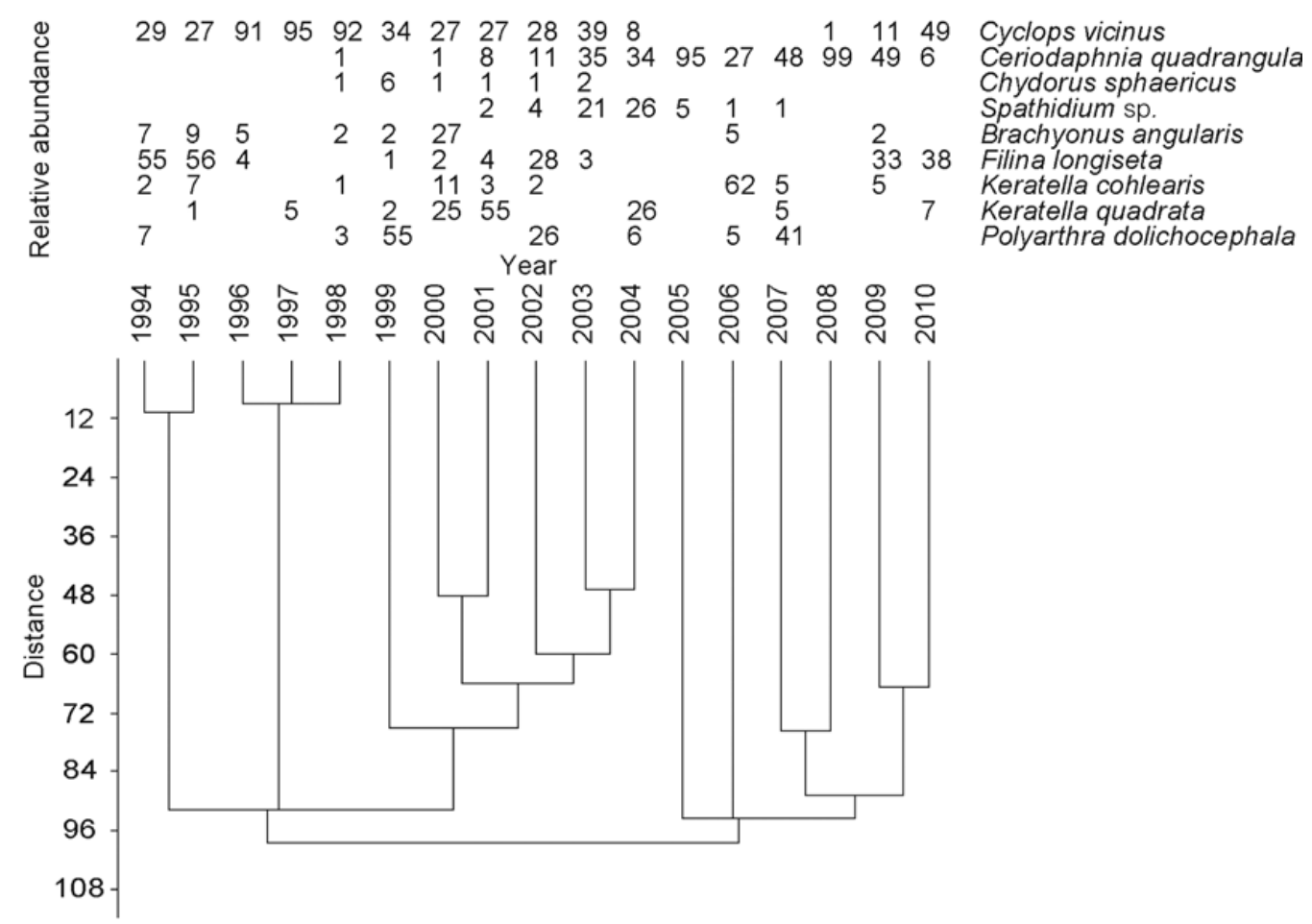

Fig. 2. Stratigraphically constrained cluster analysis with a list of species and their relative abundance at the end of summer ( = September) in Lake Krn (Slovenia) between 1994 and 2010.

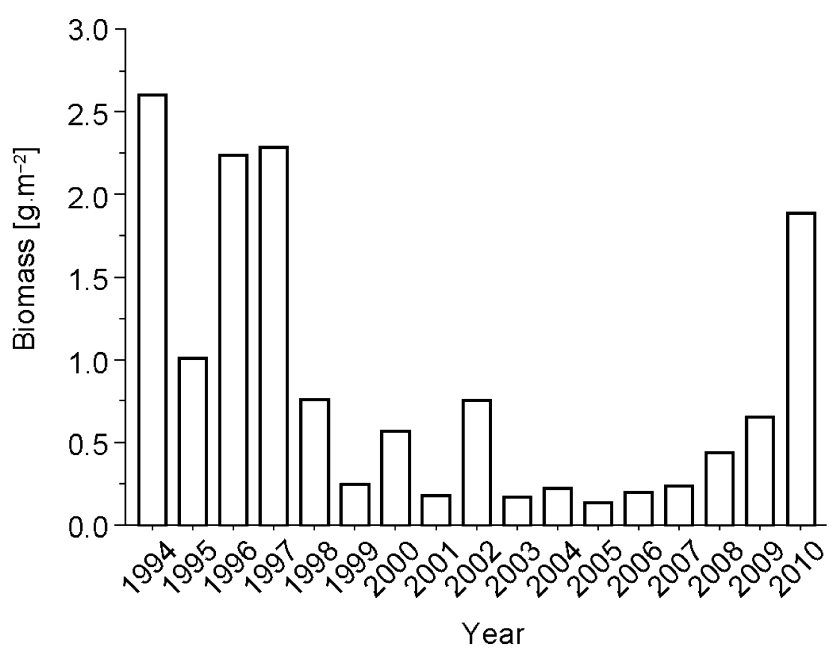

Fig. 3. Zooplankton biomass at the end of summer ( = September) in Lake Krn (Slovenia) between 1994 and 2010.

serrulatus (Fischer, 1851)). Minnows mainly consumed littoral Cladocera, Copepoda, larvae of Chironomidae and also some Ceriodaphnia.

\section{Zooplankton field analyses}

During the study, 15 taxa were recorded, 9 of which were abundant: Protozoa (1 taxon), Rotifera (5 taxa), Cladocera (2 taxa) and Copepoda (1 taxon). C. sphaericus and cf. Spathidium sp. were not truly planktonic and their representatives were occasionally found in the water column, along with few specimens of E. serrulatus. Specimens of two Daphnia, Daphnia pulicaria Forbes, 1873 and Daphnia longispina O.F. Müller, 1785, were also found occasionally in 1998 and 1999, respectively. Stratigraphically constrained cluster analysis of species relative abundance support division of the timeline into three periods (1994-1998, 1999-2004 and 2005-2010), delimited by both earthquakes (on April 12, 1998 and June 12, 2004) (Fig. 2). Average biomass in the lake decreased after earthquake I $(t$-test, $P<0.01)$ and remained relatively low during the following years with an increasing trend after 2005 (Fig. 3).

From 1994 to 1997, C. vicinus was the only crustacean in the zooplankton. It was also in the period between 1988 and 1993, but data were not included into analyses as different sampling methods/equipments were used. In September 1998, after earthquake I, few individuals of C. quadrangula were recorded. Next, C. vicinus decreased and $C$. quadrangula increased (Fig. 4). In 2005, a year after earthquake II, no $C$. vicinus specimens were seen, while a dense population of $C$. quadrangula had developed. In 2008, with $C$. quadrangula still thriving, few individuals of C. vicinus had re-appeared. In 2009, C. vicinus increased further and by summer 2010 it had re-established a dominant position (Fig. 4). A Pearson correlation coefficient confirmed the negative correlation between $C$. quadrangula and $C$. vicinus $(r=-0.621, P<0.01)$. Another cladoceran species, $C$. sphaericus, which is a littoral species, appeared in low numbers in the water column immediately after earthquake I and disappeared in the year when earthquake II occurred. 
Table 2. Multiple regression analysis on C. vicinus (Uljanin, 1875) and C. quadrangula (O.F. Müller, 1785) abundance in Lake Krn (Slovenia) ( $T_{\text {epi }}$ is the temperature of epilimnium).

\begin{tabular}{|c|c|c|c|c|c|}
\hline & & Coefficient & Std. error & $t$ & $P$ \\
\hline \multirow[t]{5}{*}{$\overline{\text { Cyclops }}$} & Constant & 31.5 & 29.9 & 1.05 & $\overline{0.3}$ \\
\hline & $P_{\text {tot }}$ & 0.8 & 0.3 & 2.6 & $<0.05$ \\
\hline & Biomass & 20.9 & 6.5 & 3.2 & $<0.01$ \\
\hline & $T_{\text {epi }}$ & -2.4 & 1.8 & 2.3 & $<0.05$ \\
\hline & Chl- $a$ & -4.1 & 3.7 & 1.1 & $<0.05$ \\
\hline \multirow[t]{6}{*}{ Ceriodaphnia } & Constant & 269.5 & 121.7 & 2.2 & $<0.05$ \\
\hline & Biomass & -34.3 & 8.5 & -4.1 & $<0.01$ \\
\hline & Chl- $a$ & -9.6 & 4.7 & -2.5 & $<0.05$ \\
\hline & $N_{\text {tot }}$ & -17.9 & 9.5 & -1.9 & $<0.05$ \\
\hline & Secchi & 5.8 & 2.9 & 1.9 & $<0.05$ \\
\hline & Alkalinity & -0.09 & 0.05 & -1.7 & $<0.05$ \\
\hline
\end{tabular}

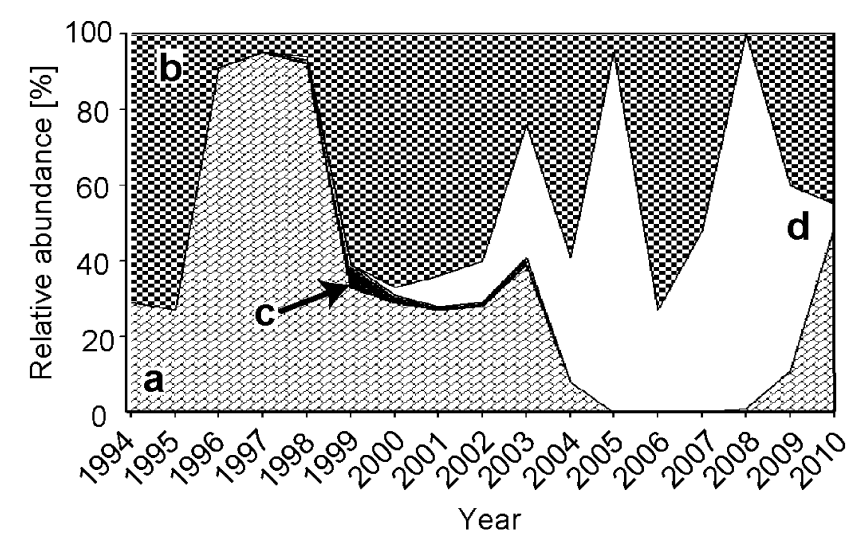

Fig. 4. Relative abundances of C. vicinus Uljanin, 1875 (a), Rotatoria (b), C. sphaericus (O.F. Müller, 1785) (c) and C. quadrangula (O.F. Müller, 1785) (d) at the end of summer (= September) in Lake Krn (Slovenia) between 1994 and 2010.

\section{Species - environment relations}

The multiple regression model with Cyclops as the dependent variable showed four environmental variables that explain $66.8 \%$ of the variance $\left(F=6.04, R^{2}=0.668\right.$, $P<0.01)$. The included variables were $P_{\text {tot }}$, epilimnion temperatures, biomass and Chl- $a$. The last two, together with $N_{\text {tot }}$, Secchi-disc depth and alkalinity, were also included when Ceriodaphnia was the response variable. This model explained $74.4 \%$ of the variance $(F=6.39$, $\left.R^{2}=0.744, P<0.01\right)$ (Tab. 2).

In the CCA, two environmental gradients are apparent. The first axis (eigenvalue $=0.345, F$-ratio $=3.237$, $P<0.05)$ represents a gradient from high biomass and phosphorous content to high alkalinity and Secchidisc depth. The second one (eigenvalue $=0.149$, $F$-ratio $=1.602, P>0.05)$ is dominated by only one factor, $N_{\text {tot }}$. All seven environmental variables account for $52 \%$ of the variance in species data. The data points form three clusters, corresponding with the predefined time periods. The first period is dominated by $C$. vicinus and Filina longiseta (Ehrenberg, 1898). C. quadrangula dominates in Period 3. In the intermediate period, Rotatoria species are prevalent. Noteworthy are also the 2009 and 2010 data

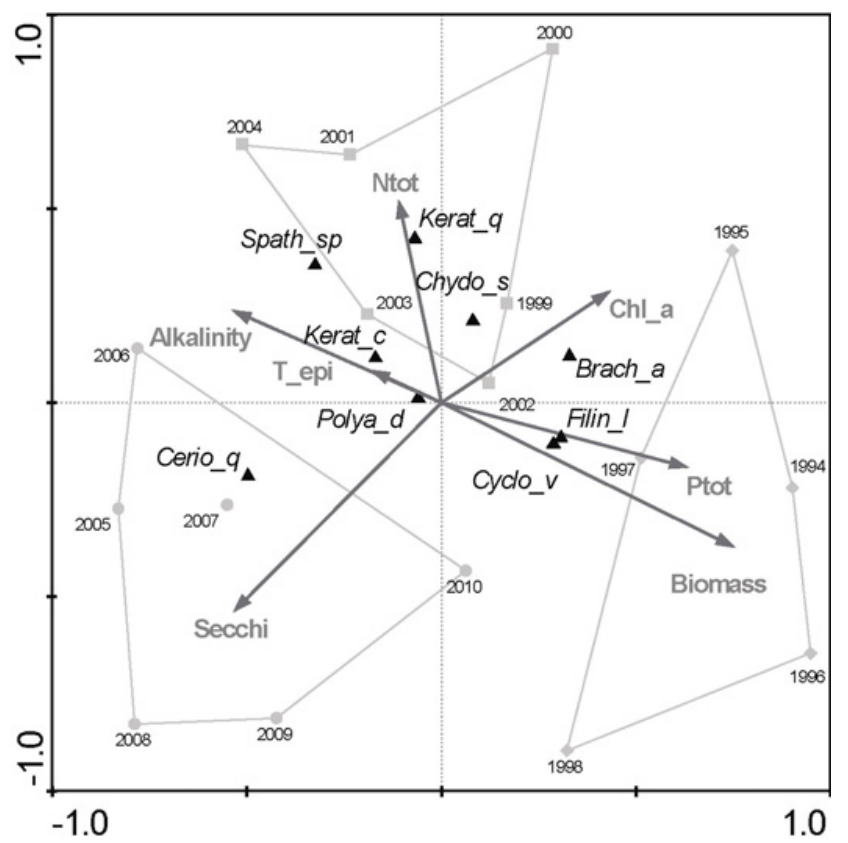

Fig. 5. Canonical correspondence analysis. Arrows: environmental variables; triangles: species centroids; diamonds: Period 1 (1994-1998); squares: Period 2 (1999-2003); circles: Period 3 (2004-2010).

points. They move away from the Period 3 group towards the Periods 2 and 1. This reflects the second change in the zooplankton community structure, with Cyclops reappearing in the water column and supplanting Ceriodaphnia (Fig. 5).

\section{Population dynamics of C. vicinus in 1996-2000}

C. vicinus hibernated in the benthos during winterspring (as copepodites CIII and CIV); its highest population in the water column occurred in late summer (as a mixture of CIII-CV stages). In September/October, approximately $70 \%$ of the population consisted of copepodites (stage CIV) and was followed by a rapid decrease of their numbers in the water column that 
Table 3. $t$-test and $P$-values for recovery test on juveniles (CIV) and adult females (CV) of $C$. vicinus Uljanin, 1875 during laboratory experiment on earthquake.

\begin{tabular}{|c|c|c|c|c|c|}
\hline Juveniles & $t$-value & $P$-value & Adult females & $t$-value & $P$-value \\
\hline$\overline{100 \% \text { start: control }}$ & 3.464 & $>0.05$ & $100 \%$ start: control & 1.000 & $>0.05$ \\
\hline Control: test & 1.000 & $>0.05$ & Control: test & 2.000 & $>0.05$ \\
\hline $10 \%$ start: control & 15.59 & $<0.01$ & $10 \%$ start: control & 1.000 & $>0.05$ \\
\hline Control: test & 26.50 & $<0.001$ & Control: test & 11.00 & $<0.01$ \\
\hline Control: control & 20.00 & $<0.01$ & Control: control & 1.000 & $>0.05$ \\
\hline Test: test & 122.0 & $<0.001$ & Test: test & 3.780 & $>0.05$ \\
\hline
\end{tabular}

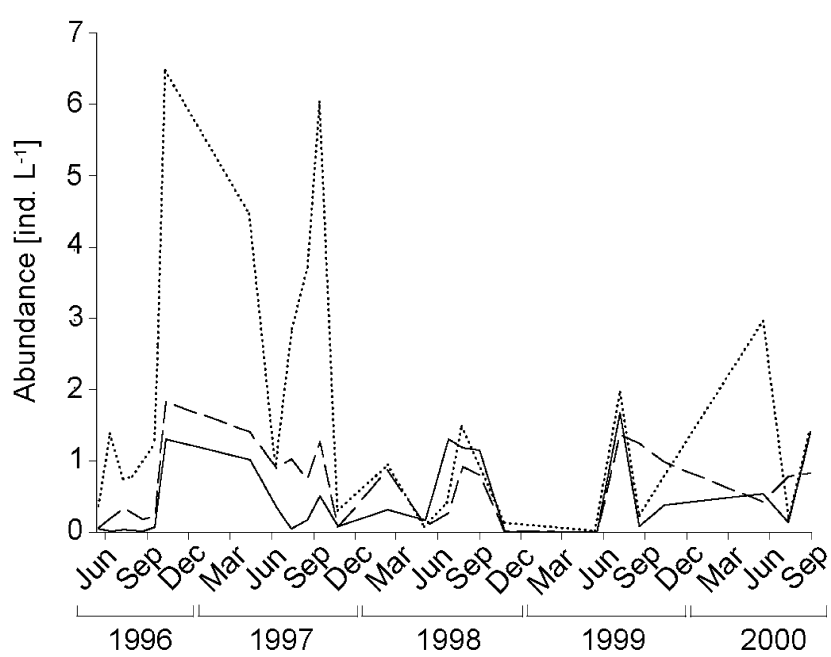

Fig. 6. Absolute abundance of C. vicinus Uljanin, 1875 between spring 1996 and autumn 2000 in Lake Krn (Slovenia). Solid line: adult females (includes females with egg sacs); dashed line: adult males; dotted line: juveniles.

remained low throughout winter (when only stage CV was present). Three weeks after earthquake I on April 12, 1998, few individuals appeared in the water column, which resulted in few males, females without eggs and juveniles ( $<1$ individual. $\mathrm{L}^{-1}$ of each group) in late summer (Fig. 6).

\section{Laboratory earthquake simulation}

The experiment that mimics an earthquake revealed that about $90 \%$ of the narcotised copepodites (CIV and $\mathrm{CV}$ ) regained activity in oxygenated lake water, regardless of whether they were covered with an additional layer of sediment or not ( $t$-test, $P>0.05$ ). In contrast, copepodites in de-oxygenated water showed a survival rate of only about $10 \%$. There were also differences in age. Young specimens in de-oxygenated water hardly survived, while adult females recovered (Tab. 3).

\section{Discussion}

Two earthquakes, on April 12, 1998 and on June 12, 2004, severely affected the population of $C$. vicinus in Lake Krn. Other high-mountain lakes in its surroundings are populated with different zooplankton species, viz. D. longispina, Arctodiaptomus alpinus (Imhof, 1885) and Cyclops abyssorum tatricus (Kozminski, 1927). All these were monitored in the same way, and at the same time, as Lake Krn, and no changes in their zooplankton community were recorded. The only significant changes in Lakes Dvojno Jezero and Črno Jezero were the result of fish introductions (Brancelj, 1999; Brancelj, personal observation). As all the lakes without fish are smaller and shallower than Lake Krn, the effects of earthquakes on their sediment were minimal or nil. Lake Ledvica, similar in size to Lake $\operatorname{Krn}$ ( $15 \mathrm{~m}$ deep, area of $2.2 \mathrm{ha}$ ) is oligotrophic, with well mineralised sediment and no nearbottom oxygen depletion and thus differs significantly from Lake Krn (Brancelj et al., 2000b).

At the time of the earthquake, $C$. vicinus of Lake Krn were still hibernating, and consisted of copepodites (mainly as CIV) lying on top of the sediment. We expect the majority to have become covered by a layer of resuspended sediment as a result of the earthquakes. Some may have escaped earthquake I and started to build a new population (Figs. 2 and 4), but were already accompanied by $C$. quadrangula that developed a dominance after earthquake II (Figs. 2 and 4). Earthquake II indeed decimated the hibernating, reduced population of C. vicinus a second time. Only in 2008 it could build a large enough population to become "visible" again in zooplankton samples; 2 years later it was again dominant. Although earthquake II reduced $C$. vicinus below the limit of detection, some specimens obviously survived. The neighbouring mountain lakes are all populated by C. abyssorum tatricus (Brancelj, 2002). The nearest lake with $C$. vicinus is Lake Bled, at an elevation of $525 \mathrm{~m}$ and $34 \mathrm{~km}$ to the west. It is unlikely that specimens were transported from there in such a short period and the most probable source of specimens for re-building the population was the lake itself.

In the period between both earthquakes there was a coexistence of three crustacean species in the water column: pelagic $C$. vicinus, littoral $C$. quadrangula and benthic C. sphaericus (Fig. 2). The last one completely disappeared from the water column after earthquake II. Its presence in the plankton requires a development of blue-green algae forming algal flakes to which it periodically attaches itself (Smirnov, 1971), a behaviour also observed in the eutrophic high-mountain Lake Dvojno Jezero (TNP), where mats of filamentous green algae were present (Brancelj, personal observations). As the concentration 
of Chl- $a$ in the year immediately after earthquake I increased and then fluctuated until earthquake II, earthquake I triggered phytoplankton growth, including filamentous algae, supporting C. sphaericus. Earthquake II induced no additional increase of Chl- $a$.

Temperature does not support the idea that warming of the epilimnion affected $C$. vicinus and favoured the thermophilic C. quadrangula. Actually, cladocearns decreased in 2008-2010, when epilimnetic temperatures were relatively high - between 20 and $23^{\circ} \mathrm{C}$ (maximum in 2010). To avoid such high temperatures, $C$. vicinus performs diurnal vertical migrations (Dussart and Defaye, 2001), which is much less than the case in littoral Ceriodaphnia.

As earthquake I induced only insignificant (or at least brief) changes and earthquake II had no effect on the water column chemistry (Fig. 5), we conclude that other factors, viz. mechanical effects of re-suspension of sediments, played the main role in the zooplankton community reversal. A (localised) effect of the earthquakes on the water column chemistry is seen in the brief planktonic episode of C. sphaericus. After earthquake I, additional nutrients released from the sediment supported planktonic algal colonies that functioned as "base-camps" for benthic species. No such evidence exists for the period after earthquake II, when no differences in the water column chemistry existed at all, although there were significant changes in the zooplankton community (Figs. 2, 4 and 5).

In Alpine lakes, average sedimentation is $<1 \mathrm{~mm}^{\mathrm{yr}}{ }^{-1}$ (Appleby, 2000). Under such conditions, copepodites rise from the sediment quite easily. But if buried after resuspension of the sediment, due to earthquakes or slumps (see Brancelj et al., 2000b), the animals would have difficulty re-emerging. Additionally, buried copepodites would be exposed to an environment low in oxygen (Wetzel, 2003). Increased oxygen concentration during spring turnover acts as a signal to stop hibernation (Dussart and Defaye, 2001). But in Lake Krn after the earthquakes $C$. vicinus copepodites may have failed to detect increasing oxygen concentrations during spring turnover. In mesotrophic lakes, the penetration of oxygen into sediment during spring and autumn overturn is limited to few millimetres and is a slow process (Wetzel, 2003). Lake Krn was mesotrophic when the earthquakes occurred, and oxygen concentrations in the hypolimnion dropped below $1 \mathrm{mg} . \mathrm{L}^{-1}$ (Muri and Brancelj, 2002).

Sediment analyses in another regional mountain lake, Lake Ledvica, revealed an increased sedimentation rate after each earthquake (Brancelj et al., 2000b). It has also been demonstrated that significant amounts of gas can be released from the bottom of a lake by seismic activity (Wetzel, 2003; Radziminovich et al., 2010). Bubbles of methane $\left(\mathrm{CH}_{4}\right)$ or carbon dioxide $\left(\mathrm{CO}_{2}\right)$ trapped in the sediment are released and re-suspended in a thin layer of mud just above the bottom by earthquakes and this may have been sufficient to cover $C$. vicinus in Lake Krn with a layer of sediment. Re-suspension was probably of short duration: no increased turbidity above the lake bottom was detected few weeks after earthquake I (Brancelj et al., 2000b). Our simple laboratory experiment demonstrated that even a slight cover of sediment had significant effects on copepodite survival under hypoxia or anoxia. Admittedly, physiological conditions of narcotised and dormant copepodites are not necessarily identical. However, their dormancy in the lake was close to its end and the animals' energy storage was low and "nondormant" enzymes were probably already activated. Thus, we expect that they were in a condition similar to narcotised copepodites. The experiment also demonstrated that narcotised copepodites CIV cannot survive in hypoxic conditions, covered by sediment, but adults can. An additional shock to these copepodites may have been a pre-earthquake groundwater chemistry change, as reported in L'Aquila (2009): "During tectonic activities highly mobile electronic charge carriers are activated. When they arrive at the rock-water interface, they act as oxygen radicals, oxidizing water to hydrogen peroxide" (Grant et al., 2011). These authors found that toads (B. bufo) left their breeding site few days before the earthquake and did not return until after the aftershock series subsided. Hydrogen peroxide is toxic, and may have killed immobile copepodites, with the subsequent blanket of sediment simply increasing its lethal effects.

There is a fundamental difference in over-wintering strategy between $C$. vicinus (Copepoda) and $C$. quadrangula (Cladocera). In autumn, copepodites of $C$. vicinus sink to the bottom, at a constant low temperature $\left(4{ }^{\circ} \mathrm{C}\right)$ and frequent hypoxia/anoxia occurs (Santer, 1998; Dussart and Defaye, 2001). They diapause there until spring, slowly utilizing energy reserves. C. quadrangula, in contrast, produces resting eggs (ephippia), which collect in the littoral zone where there is no oxygen depletion. In spring, as a result of parthenogenetic reproduction, Cladocera reach high densities in a comparatively short time (Dumont and Negrea, 2002).

Ephippia can survive for years or even decades before hatching (Dumont and Negrea, 2002; Fox, 2007). Thus, copepodites in diapause are vulnerable to external disturbances, while cladoceran ephippia are not or are so to a much lesser degree. Another factor was the timing of both earthquakes: indeed, in spring, copepodites were still in dormancy. Had the earthquakes occurred a month later, the copepods would have left the benthos, and the effect of the earthquake would probably have been nil.

We conclude that the sudden decrease of the omnivorous C. vicinus in early spring 1998 and its radical elimination in 2005 were a direct consequence of a physical disturbance, perhaps combined with a potential change in groundwater chemistry, rather than food shortage. Its demise created an ecological void that was filled by the opportunistic $C$. quadrangula for about a decade. This suggests that this small-bodied cladoceran is normally suppressed by the copepod, even though its development time is of the order of a week only, while the copepod has one generation per annum. Gliwicz et al. (2001) found that 
C. abyssorum can, under specific conditions, control largebodied Daphnia by eating its eggs and neonates. In a case of $C$. vicinus and C. quadrangula, the copepod's herbivorous/omnivorous way of feeding suggests that competition was far more important. When $C$. vicinus was decimated, C. quadrangula temporarily took over. However, the gradual re-appearance of $C$. vicinus is evidence for its superiority in exploitation, although full recovery required seven generations. During this recovery, there was no significant change in water chemistry, and thus, neither the decline of $C$. quadrangula nor the increase of $C$. vicinus was caused by environmental change. Eventually, $C$. quadrangula was only found in the weedy littoral of the Lake Krn, where its numbers were controlled by minnows. These do not venture in the open water, where they are chased by Arctic char. Adult Arctic char does not consume pelagic $C$. quadrangula because it is too small and limited to the upper epilimnion where temperatures are too high for this fish, which comes to surface only briefly to catch bigger prey, like air-borne insects. Adult C. vicinus, on the other hand, is too agile to be consumed in numbers. Big-bodied Daphnia that appear from time to time in the Lake Krn, in contrast, are probably eliminated by the fish. Schabetsberger et al. (2009) reported relatively quick shifts (2-5 years) from large bodied zooplankton (Mixodiaptomus laciniatus (Lilljeborg, 1889), A. alpinus, Daphnia rosea G.O. Sars, 1862) to small bodied (Ceriodaphnia pulchella G.O. Sars, 1862, and several species of Rotifera) after Arctic char introduction to high-mountain lakes in Austria. In another lake, soon after piscivorous trout (Salmo trutta fario Linnaeus, 1758) had been introduced, the population of minnows was reduced and small-bodied $C$. pulchella was replaced by more competitive D. longispina (Schabetsberger et al., 2006). The situation observed in zooplankton change in Lake Krn was essentially similar, but an earthquake, not fish, temporarily suppressed a successful competitor ( = C. vicinus).

Acknowledgements. Thanks to all colleagues who helped during the field work. Part of the study was performed within EU projects MOLAR and EMERGE (contracts ENV4-CT950007 and EVK1-CT-1999-00032). The study was partly supported by the Slovenian Ministry of Higher Education, Science and Technology (Slo-Alpe: J1-7414). The authors would thank two anonymous reviewers, whose comments helped to improve the paper and to Dr Julia Ellis Burnet for linguistic corrections.

\section{References}

Appleby P.G., 2000. Radiometric dating of sediment records in European mountain lakes. J. Limnol., 1 (Suppl. 1), 1-14.

Battarbee R.W., Thompson R., Catalan J., Grytnes J.-A. and Birks H.J.B., 2002. Climate variability and ecosystem dynamics of remote alpine and arctic lakes: the MOLAR project. J. Paleolimnol., 28, 1-6.

Brancelj A., 1999. The extinction of Arctodiaptomus alpinus (Copepoda) following the introduction of Arctic char into a small alpine lake Dvojno Jezero (NW Slovenia). Aquat. Ecol., 33, 355-361.

Brancelj A., 2002. Fauna: Zooplankton, Benthos and Fish. In: Brancelj A. (ed.), High-Mountain Lakes in the Eastern Part of the Julian Alps, ZRC Publishing and National Institute of Biology, Ljubljana, 137-158.

Brancelj A., Šiško M., Rejec Brancelj I., Jeran Z. and Jaćimović R., 2000a. Effect of land use and fish stocking on a mountain lake - evidence from the sediment. Period. Biol., 102, 259-268.

Brancelj A., Šiško M., Lami A., Appleby P., Livingstone D.M., Rejec Brancelj I. and Ogrin D., 2000b. Changes in the trophic level of an Alpine lake, Jezero v Ledvici (NW Slovenia), induced by earthquakes and climate change. J. Limnol., 1 (Suppl. 1), 29-42.

Cammarano P. and Manca M., 1997. Studies on zooplankton in two acidified high mountain lakes in the Alps. Hydrobiologia, 356, 97-109.

Carrara P.E. and O’Neill J.M., 2003. Tree-ring dated landslide movements and their relationship to seismic events in southwestern Montana, USA. Quatern. Res., 59, 25-35; doi:10.1016/S0033-5894(02)00010-8.

Catalan J., Ventura M., Brancelj A., Granados I., Thies H., Nickus U., Korhola A., Lotter A.F., Barbieri A., Stuschlik E., Lien L., Bitušik P., Buchaca T., Camarero L., Goudsmith G.H., Kopaček J., Lemcke G., Livingston D.M., Müller B., Rautio M., Šiško M., Sorvari S., Šporka F., Strunecky O. and Toro M., 2002. Seasonal ecosystem variability in remote mountain lakes: implications for detecting climatic signals in sediment records. $J$. Paleolimnol., 28, 25-46.

Catalan J., Barbieri M.G., Bartumeus F., Bitušík P., Botev I., Brancelj A., Cogălniceanu D., Manca M., Marchetto A., Ognjanova-Rumenova N., Pla S., Rieradevall M., Sorvari S., Štefkova E., Stuchlík E. and Ventura M., 2009. Ecological thresholds in European alpine lakes. Freshw. Biol., 54, 2494-2517; doi:10.1111/j.1365-2427.2009.02286.x.

Cavalli L., Miquelis A. and Chappaz R., 2001. Combined effects of environmental factors and predator-prey interactions on zooplankton assemblages in five high alpine lakes. Hydrobiologia, 455, 127-135.

Clesceri L.S., Greenberg A. and Eaton A.D. (eds.), 1998. APHA, AWWA, WEF: Standard Methods for the Examination of Water and Wastewater, 20th edn, United Book Press Inc., Washington, 1-49.

Dobravec J. and Šiško M., 2002. Geographical location and description of the lakes. In: Brancelj A. (ed.), HighMountain Lakes in the Eastern Part of the Julian Alps, ZRC Publishing and National Institute of Biology, Ljubljana, 49-76.

Dumont H.J. and Negrea S.V., 2002. Introduction to the Class Branchiopoda. Guides to the Identification of the Microinvertebrates of the Continental Waters of the World 19, Backhuys, Leiden, 398 p.

Dussart B.H. and Defaye D., 2001. Introduction to the Copepoda. Guides to the Identification of the Microinvertebrates of the Continental Waters of the World 16 (2nd edn), Backhuys, Leiden, 344 p.

Fott J., Pražaková M., Stuchlík E. and Stuchlícová Z., 1994. Acidification of lakes in Šumava (Bohemia) and in the High Tatra Mountains (Slovakia). Hydrobiologia, 274, $37-47$. 
Fox J.A., 2007. Hatching timing of Daphnia mendotae diapausing eggs of different ages. Fund. Appl. Limnol., 168, 19-26.

Gliwicz Z.M., Slusaraczyk A. and Slusaraczyk M., 2001. Life history synchronization in a long-lifespan single-cohort Daphnia population in a fishless alpine lake. Oecologia, 128, 368-378.

Goyke A.P. and Hershey A.E., 1992. Effects of fish predation on larval chironomid (Diptera: Chironomidae) communities in an arctic ecosystem. Hydrobiologia, 240, 203-211.

Grant R.A., Halliday T., Balderer P., Leuenberger F., Newcomer M., Cyr G. and Freund F.T., 2011. Ground water chemistry changes before major earthquakes and possible effects on animals. Int. J. Environ. Res. Public Health, 2011, 1936-1956; doi:10.3390/ijerph8061936.

Grimm E.C., 1987. CONISS: a FORTRAN 77 program for stratigraphically constrained cluster analysis by the method of incremental sum of squares. Comp. Geosci., 13, $13-35$.

Gulizzoni P., Lami A., Manca M., Musazzi S., Marchetto A., 2006. Palaeoenvironmental changes inferred from biological remains in short lake sediment cores from the Central Alps and Dolomites. Hydrobiologia, 562, 167-191.

Hammer Ø., Harper D.A.T. and Ryan P.D., 2001. Paleontological Statistics Software Package for Education and Data Analysis. Palaeontol. Electr., 4, 39-48.

Heiri O., Lotter A.F., 2003. 9000 years of chironomid assemblage dynamics in an Alpine lake: long-term trends, sensitivity to disturbance, and resilience of the fauna. J. Paleolimnol., 30, 273-289.

Hořická Z., Stuchlík E., Hudec I., Martin Černý M. and Fott J., 2006. Acidification and the structure of crustacean zooplankton in mountain lakes: the Tatra Mountains (Slovakia, Poland). Biologia, Bratislava, 61 (Suppl. 18), 121-134; doi:10.2478/s11756-006-0125-6.

Jeffrey S.W. and Humphrey G.F., 1975. New spectrophotometric equations for determining chlorophylls $a, b, c_{1}$ and $c_{2}$ in higher plants, algae and natural phytoplankton. Biochem. Physiol. Pflanzen, 167, 191-194.

Jersabek C.D., Brancelj A., Stoch F. and Schabetsberger R., 2001. Distribution and ecology of copepods in mountainous regions of the Eastern Alps. Hydrobiologia, 453, 309-324.

Johnson D.M., Martin T.H., Crowley P.H. and Crowder L.B., 1996. Link strength in littoral food webs: Net effects of small sunfish and larval dragonflies. J. N. Am. Benthol. Soc., 15, 271-288.

Koinig K.A., Kamenik C., Schmidt R., Agustí-Panareda A., Appleby P., Lami A., Prazakova M., Rose N., Schnell Ø.A., Tessadri R., Thompson R. and Psenner R., 2002. Environmental changes in an alpine lake (Gossenköllesee, Austria) over the last two centuries - the influence of air temperature on biological parameters. J. Paleolimnol., 28, 147-160.

Korup O., McSaveney M.J. and Davies T.R.H., 2004. Sediment generation and delivery from large historic landslides in the Southern Alps, New Zealand. Geomorphology, 61, 189-207.

Levine S.N., Zehrer R.F. and Burns C.W., 2005. Impact of resuspended sediment on zooplankton feeding in Lake Waihola, New Zealand. Freshw. Biol., 50, 1515-1536; doi:10.1111/j.1365-2427.2005.01420.x.

Luger M.S., Schabetsberger R., Jersabek C.D. and Goldschmid A., 2000. Life cycles, size and reproduction of the two coexisting calanoid copepods Arctodiaptomus alpinus (Imhof,
1885) and Mixodiaptomus laciniatus (Lilljeborg, 1889) in a small high-altitude lake. Arch. Hydrobiol., 148, 161-185.

Muri G. and Brancelj A., 2002. Physical and chemical properties of lake water and ice cover. In: Brancelj A. (ed.), HighMountain Lakes in the Eastern part of the Julian Alps, ZRC Publishing and National Institute of Biology, Ljubljana, 91-109.

Nomade J., Chapron E. and Desmet M., 2005. Reconstructing historical seismicity from lake sediments (Lake Laffrey, western Alps, France). Terra Nova, 17, 350-357.

Radziminovich Y.B., Shchetnikov A.A. and Vologina E.G., 2010. The "methane eruption" on Lake Baikal in 1912 as an effect of a strong earthquake. Dokl. Earth Sci., 432, 583-586.

Sacherová V., Kršková R., Stuchlík E., Hořická Z., Hudec I. and Fott J., 2006. Long-term change of the littoral Cladocera in the Tatra Mountain lakes through a major acidification event. Biologia, Bratislava, 61 (Suppl. 18), 109-119.

Samuel H., Jephson T., Lebret K., Einem J., Fagerberg T., Balseiro E., Modenutti B., Souza S.S., Laspoumaderes C., Jönsson M., Ljungberg P., Nicolle A., Nilsson P.A., Ranåker L. and Hansson L.-A., 2011. Climate-induced input of turbid glacial meltwater affects vertical distribution and community composition of phyto- and zooplankton. J. Plankt. Res., 33, 1239-1248.

Santer B., 1998. Life cycle strategies of free-living copepods in fresh waters. J. Mar. Syst., 15, 327-336.

Schabetsberger R., Grill S., Hauser G. and Wukits P., 2006. Zooplankton successions in neighboring lakes with contrasting impacts of amphibian and fish predators. Internat. Rev. Hydrobiol., 91, 197-221.

Schabetsberger R., Luger M.S., Drozdowski G. and Jagsch A., 2009. Only the small survive: monitoring long-term changes in the zooplankton community of an Alpine lake after fish introduction. Biol. Inv., 11, 1335-1345.

Smirnov N.N., 1971. Chydoridae fauny mira. Fauna SSSR. Rakoobraznye $=$ Chydoridae Fauna of the World. Fauna of the USSR. Crustaceans. Nauka, Leningrad, $531 \mathrm{p}$.

Sommaruga R., 2001. The role of UV radiation in the ecology of alpine lakes. J. Photoch. Photobiol., B-Biol., 62, 35-42; doi:10.1016/S1011-1344(01)00154-3.

Šiško M. and Kosi G., 2002. Algae. In: Brancelj A. (ed.), HighMountain Lakes in the Eastern Part of the Julian Alps, ZRC Publishing and National Institute of Biology, Ljubljana, 111-128.

Šporka F., Štefková E., Bitušík P., Thompson A.R., AgustíPanareda A., Appleby P.G., Gryntes J.A., Kamenik C., Krno I., Lami A., Rose N. and Shilland N.E., 2002. The paleolomnological analysis of sediments from high mountain lake Nizne Terianske Pleso in the High Tatras (Slovakia). J. Paleolimnol., 28, 95-109.

ter Braak C.J.F. and Smilauer, P., 2002. CANOCO - Software for Canonical Community Ordination (version 4.5). Microcomputer Power, Ithaca.

Theis, H., 1994. Chemical properties of an acidified humic headwater lake with respect to reducing acidic depositions and expected climate-change. Hydrobiologia, 274, 143-154.

Vidrih R., 2008. Potresna dejavnost Zgornjega Posočja [Seizmic activity of the Upper Posočje area]. Agencija republike Slovenije za okolje, Urad za seizmologijo in geologijo 
[Environmental Agency of the Republic of Slovenia, Seizmology and Geology office], Ljubljana, 352 p.

Vinebrooke R.D. and Leavitt P.R., 1998. Direct and interactive effects of allochthonous dissolved organic matter, inorganic nutrients, and ultraviolet radiation on an alpine littoral food web. Limnol. Oceanogr., 43, 1065-1081.
Wograth S. and Psenner R., 1995. Seasonal, annual and longterm variability in the water chemistry of a remote high mountain lake: Acid rain versus natural changes. Water Air Soil Poll., 85, 359-364.

Wetzel R.G., 2003. Limnology. Lake and River Ecosystems (3rd edn), Academic Press, London, 1006 p. 